\title{
The Countermeasures and Existing Problems of Translation Teaching in College English
}

\author{
Hongxia Dai, a , Zhongmeng Chen ${ }^{2, b}$ \\ ${ }^{1}$ School of National Education, Nanchang Institute of science \& Technology, Nanchang 330108, \\ China; \\ ${ }^{2}$ Foreign Languages School, Nanchang Normal University, Nanchang 330032, China; \\ aluochenpaper@163.com; bcsuzju@163.com
}

Keywords: College English, Translation Teaching, Problem, Countermeasure

\begin{abstract}
Translation teaching is important part in college English teaching, and also main approach to train translated talented person. College English translation teaching have contributed to developing good learn habit, improving students' comprehensive abilities. For a long time, college translation teaching have lacked of attention and overall plan. In addition, there are some problems, such as weak teaching personnel, old teaching model and weak language basis, etc. To train culture the translation talented personnel for economic and social development, colleges and universities must improve the college English teaching syllabus, reform teaching content and change teaching mode and reinforce the construction of teachers group, so as to raise the teaching reform in colleges and universities English teaching to a new level.
\end{abstract}

\section{Introduction}

In the rapid development of social life information and economic globalization today, external exchanges have extended into the whole society as well as fields of science and the economy. More and more translations personnel are needed by relative industry and company. At present, our country needs more and more complex talents have become an indisputable fact. However, looking far and wide of our college English teaching history and situation, there are a lot of issues. Colleges and universities have ignored translation teaching or not noticed the importance of translation teaching, which have resulted in the defect of English applying ability. Therefore, it is imperative that colleges and universities reform the situation of college English translation teaching and improves the abilities of translation [1].

\section{Existing Problems of Translation Teaching In colleges and university English}

At present, the college English is an important course in college basic teaching stage. College English intensive reading and English listening have become compulsory courses in most universities. Skill of learning, speaking, writing, reading and translating are five basic skills of English talents. In the total setting of college English courses view, the first four are big part, and the translating teaching is a small portion. In addition, in the colleges, teachers and students view, translating teaching is not highly regarded in colleges and universities teaching [2-3]. The translating teaching of college English cannot keep the same pace with China's economic development. The English translation teaching is not ideal, and on the margins of the college English teaching. The English translation teaching is out of touch with reality.

College and University English Teaching Lacks the Whole Planning and Design. Analyzing the some existing college English curricula and textbooks, we can find some English curricula and textbooks lack of introduction of translation theories and skills. These curricula and textbooks seldom refer to train the "translation" abilities. The current status make teachers reluctant to operate in practice teaching and only limit implement translation training after class. College teaching syllabus was modified by Chinese Education Minister in 2004. The revised syllabus for College English has 
made specific requirements for English teaching in china. Students are required to master English-Chinese translation by using dictionary, translation from English to Chinese speed of 300 words per hour, and translation from Chinese to English speed of 250 words per hour. In addition, students can implement English-Chinese translation by using translation techniques. This requirement doesn't improve the students' attention on translation, but cause misunderstanding to translation [4]. They think that they can only translate articles by using dictionary. This makes teachers and students neglect the cultivation of translation ability. They believe that they translate the article in accordance with dictionary meaning.

The teaching goal of new edition of syllabus for college courses is to train English complex abilities of college students. Here refers to the cultivation of listening and speaking abilities, which neglects the requirement of translation ability. At present, the colleges and universities teaching have based on CET exams. Though the translation type has become a type of question in CET4 and CTT6 exam, the translate exercise has only account for $5 \%$ of total scores. This is much less than the desired college teaching.

The College Pays Less Attention to Teaching Content in Translation Teaching. At present, course content of the college is inadequate. Some colleges and universities only offer two hour once a week. The cause is that the colleges and universities have long been unable to call attention to the translation course. The approach will make students bring negative impact on translation course to some extent. Many college English textbook don't involve any translation theory and translation skills [5]. It seems that college English translation teaching has on the edge of college English teaching. Some college teachers misunderstand that listening, speaking, writing and reading are stress of teaching. And this view can make students vulnerable to accept at the baton of examination-oriented education system, and make easily students neglect the importance of translation learning and translation ability.

The Translation Teaching has Long been Limited to the Traditional Teaching Mode. Survey shows the current teaching mode of translation teaching have limited the traditional teaching mode. The teaching ideas have not put the ideas of innovative new mode. Most teaching modes have implemented the examination-oriented education. Students play the role of passive learning in class. The teaching mode cannot mobilize the enthusiasm of students. That way, the effect of English teaching is not ideal. And specifically, limitation is showed in these aspects: first, the teaching mode is dull, teacher implements teaching with fixed textbook and teaching model; second, class is large, so that the teacher and students cannot exchange their on equal basis. In addition, group discussions were restricted as well. Third, the college English teaching has limited class. Teachers cannot teach much of translation knowledge in a limited time, and students are not very good at digesting and absorbing them.

College English Translation Teaching Faculty is Weak. The college English teaching focuses on improving the reading, speaking, reading and writing abilities of college student. The translation ability is ranked at the bottom of reading, writing, speaking and listening, the important reason is that college translation is a comprehensive course [6]. This requires college teachers to master expertly knowledge of Chinese- English bilingual and cross-cultural communication. With the increasing of universities, the number of students has sustained enlargement of an increasingly large in recent years. Some new college English teachers are short of teaching experience and translation theory literacy. And some experienced teachers retire from teaching because of personal element or others. This will result in a lack of teaching faculty in college English translation teaching.

No-English Majors Students' Language Basis is Quite Poor. There are questions in college English Translation teaching. And poor language basis is one of the important reasons. Some abilities of overall quality and language understanding are relatively poor in not only English, but also mother language. These problems hinder translation abilities development of students. English learning in high school is major source of learning English knowledge. During their high school, the English teachings are the exam-oriented education. They have attached great importance to train some abilities of reading, writing, listening and speaking, while ignored the training of translation skills. So 
they often neglect to translation. As a result of high school English teaching, most college students frequently neglects translation learning, and fail to realize the importance of translation. They think that they just simply understand the meaning of sentence and sentence groups. They are no deeply research on translation knowledge. In addition, it is important for translation processing to understand language context and background. Any one language is related to the language context and cultural background. Therefore, if students are lack of language context or related cultural background, it will lead to misunderstand the language knowledge. They cannot accurately grasp the original meaning of language because of misunderstanding of language context and cultural background during translation. This way, mistakes are usually made in the translation learning.

\section{The Countermeasures of Improving College English Translation Teaching.}

In order to solve these problems, some countermeasures should be implemented in the current translation teaching. How to make the college English translation teaching meet the needs of the developing conditions, have become an urgent to be solved in colleges. College need have a positive attitude to the translation teaching in college English teaching.

Improving College English Teaching Syllabus and Attaching Great Importance of College English Translation Teaching. The current college English Teaching syllabus places different demands on the no-English majors, but all focus on developing students' English comprehensive abilities. College English teaching only emphasizes four abilities of reading, listening, writing and speaking, and neglects the ability of translation. There is no sufficient attention to the translation. Most colleges have implemented English teaching of no-English majors in accordance with syllabus. So in syllabus, one should make it that the translation plays in important role on college English teaching in syllabus. In addition, it needs to attach great importance to translation theories and skills. And the translation should be attached more attention than ever In CET examination, so as to increase attention with teaching and learning of translation. In addition, colleges should also introduce the new concept of translation theory and skills.

Reforming the Teaching content of College English and Improving the curriculum. At present, the amount of abilities of speaking, writing, reading and listening training are adequate in most colleges, translation is inadequate. One should introduce moderate translation content and translation skills to textbooks. But it also brings some problems, such as insufficient class time. So colleges should also increase class time in college translation teaching. In addition, college teachers should hold translation lectures and open some elective courses, such as translation skill, western culture, culture \& translation and intercultural communication, etc. These courses can simulate and promote students' interest of the translation course, also compensate the lack of knowledge from basic stage.

Reforming the College English Teaching Model and Optimizing the Teaching Organization. The success of college English translation teaching depends on teaching mode. The authors think the right model mainly shows in three aspects. In the first place, it embodies the student-centered teaching concept. Teachers need understand the content of translation course fundamentally. The college translation teaching should put emphasis on students-centeredness, and simulate the student's enthusiasm and initiative. In the second place, college should open some optional courses according to different level students, which includes some optional courses of basic properties (translation theory \& skill) and comprehensive optional courses. In the third place, teachers should teach the translate courses in accordance with the specific needs of students, and acquire timely the feedback information.

Strengthening the Construction of the Faculty Team of College English Translation Teaching. At present, most teachers have taken the literature, linguistics as their main research direction, neglect the translation theory. Therefore, it is necessary to strengthen the continuous education. College teachers should continue to pay attention to the translation theory, translation history and interpreting skills. In addition, English teachers also should enhance the ability of study 
and adopt life-long learning concept, and improve their own quality, so as to follow the tide. In addition, English teaching should understand cultures all over the world and other knowledge of other branches of science.

Enhancing Language Comprehensive Capabilities of Students and Making up the Translation Abilities. The most important things to change the students' wrong understandings. In addition, it is also important to correct study attitude of students. The transform of learn attitude has a big influence on translation learning. In process of teaching, teachers should focus on enhancing students' vocabulary, and strengthen the teaching of translation skills. In addition, teachers also should teach different translation skills, so as to enhance knowledge base of translation. Students should paid attention to strengthen learning and study of background knowledge and context. Meaning of one language depends very much on culture background and context. It is important for improving students' translation abilities to dabble widely native language and related culture. The author thinks that translation should be able to adjust duly in accordance with language context and cultural background besides with dictionary. Besides that, college and university students also should enlarge some related knowledge by using their off-hours, such as cultural background and language context, etc. Only in that way, it is possible to make college and university students grasp really translation quintessence and skills.

\section{Summary}

With the rapid development of our social economy, our country needs more and more complex and applied translation talents. The college English translation teaching plays an important role in training students' translation abilities. It also become an important way that improving abilities of English knowledge and English comprehensive application. Students and teachers should pay attention to college English translation, and improve the learning and teaching in practice. As the same time, teachers should pay attention to application and innovation of teaching mode, so as to stride a new step.

\section{References}

[1] J.G.CAI. On the Necessity and Feasibility of Taking the Translation Course on the Part of College Student, Chinese Translators Journal, 3(2010): 63-65.

[2] G.Q.CHEN. Exploration of Translation Teaching and College English Teaching Translation, Chinese Translators Journal, 3(2010): 124-127.

[3] H.R.ZHANG. Problems in the College English Translation Teaching and Countermeasures, Theory and Practice of Education, 30(2010): 62-64.

[4] D.F.SU, Z.X.ZHUANG. Modern Foreign Languages Teaching---Theory, Practice and Method, Shanghai: Shanghai Foreign Language Education Press,2008,6:111-116.

[5] S.Y.LU,Q.J.WU. Outlook of Study and Translation Teaching in the New Century, Chinese Translators Journal, 06(2011): 10-13.

[6] L.C.WEI. Translation Theory and Translation Teaching, Foreign Language Education, 14(2010): 110-113. 